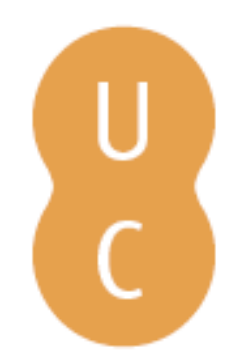

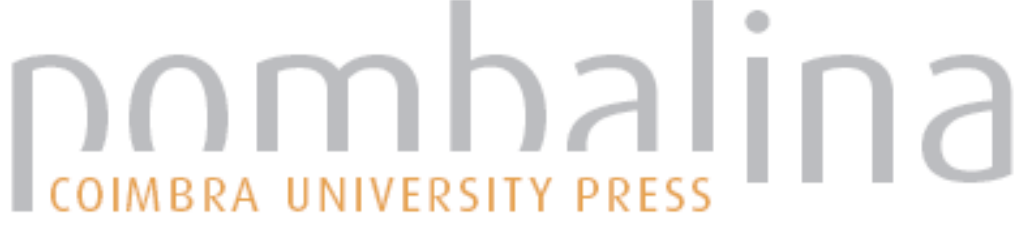

\section{A nostalgia da eternidade e o ideário contrarevolucionário}

Autor(es): $\quad$ Castro, Zília Osório de

Publicado por: Imprensa da Universidade de Coimbra

URL

persistente: URI:http://hdl.handle.net/10316.2/31643

DOI: $\quad$ DOI:http://dx.doi.org/10.14195/978-989-26-0199-1_33

Accessed : $\quad$ 26-Apr-2023 09:06:21

A navegação consulta e descarregamento dos títulos inseridos nas Bibliotecas Digitais UC Digitalis, UC Pombalina e UC Impactum, pressupõem a aceitação plena e sem reservas dos Termos e Condições de Uso destas Bibliotecas Digitais, disponíveis em https://digitalis.uc.pt/pt-pt/termos.

Conforme exposto nos referidos Termos e Condições de Uso, o descarregamento de títulos de acesso restrito requer uma licença válida de autorização devendo o utilizador aceder ao(s) documento(s) a partir de um endereço de IP da instituição detentora da supramencionada licença.

Ao utilizador é apenas permitido o descarregamento para uso pessoal, pelo que o emprego do(s) título(s) descarregado(s) para outro fim, designadamente comercial, carece de autorização do respetivo autor ou editor da obra.

Na medida em que todas as obras da UC Digitalis se encontram protegidas pelo Código do Direito de Autor e Direitos Conexos e demais legislação aplicável, toda a cópia, parcial ou total, deste documento, nos casos em que é legalmente admitida, deverá conter ou fazer-se acompanhar por este aviso.

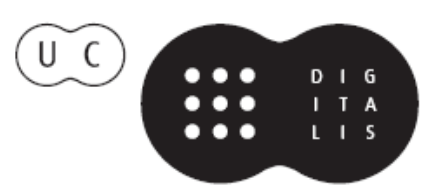


Maria Manuela Tavares Ribeiro

Coordenação

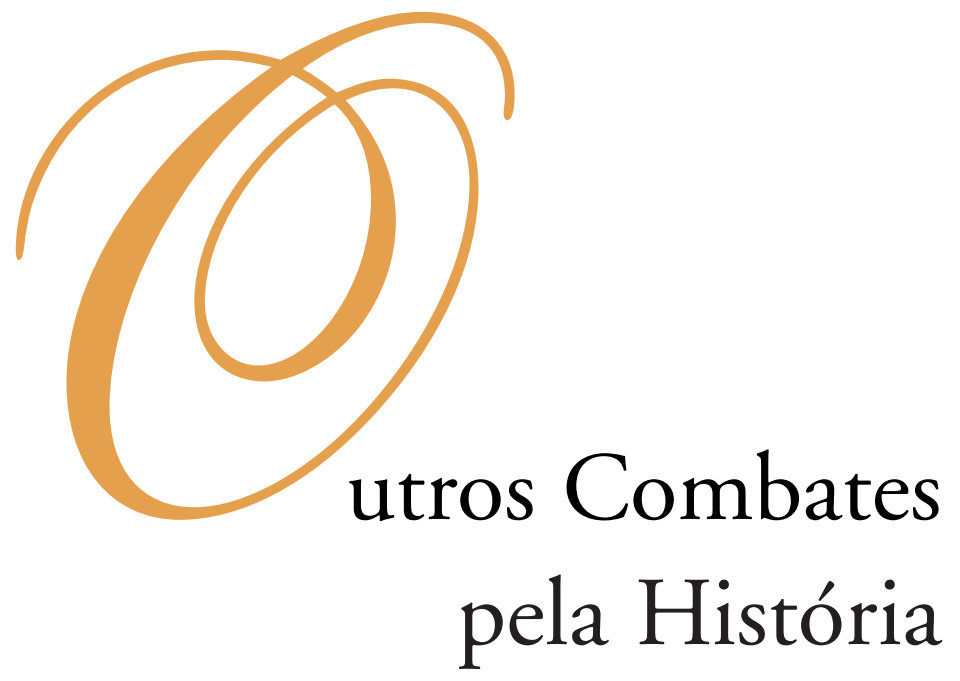




\section{COORDENAÇĀO EDITORIAL}

Imprensa da Universidade de Coimbra

Email: imprensauc@ci.uc.pt

URL: http://www.uc.pt/imprensa_uc

Vendas online: http://livrariadaimprensa.com

\section{CONCEPÇÃO GRÁFICA}

António Barros

\section{ORgANIZAÇĀO DOS TEXTOS}

Isabel Maria Luciano

Marlene Taveira

PRÉ-IMPRESSÃO

António Resende

Imprensa da Universidade de Coimbra

EXECUÇÃO GRÁFICA

SerSilito • Maia

ISBN

978-989-26-0041-3

DEPósito LEGAL

OBRA PUBLICADA COM O APOIO DE:

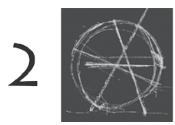

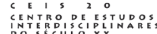

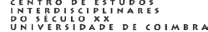

FCT Fundação para a Ciência e a Tecnologia

MINISTÉRIO DA CIÊNCIA, TECNOLOGIA E ENSINO SUPERIOR Portugal

Programa Operacional Ciência, Tecnologia, INOVAÇĀo DO QUADRo COMUNITÁRIO DE APOIO III

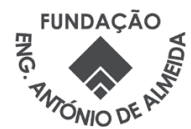

C JULHO 2010, IMPRENSA DA UNIVERSIDADE DE COIMBRA 
Maria Manuela Tavares Ribeiro

Coordenação

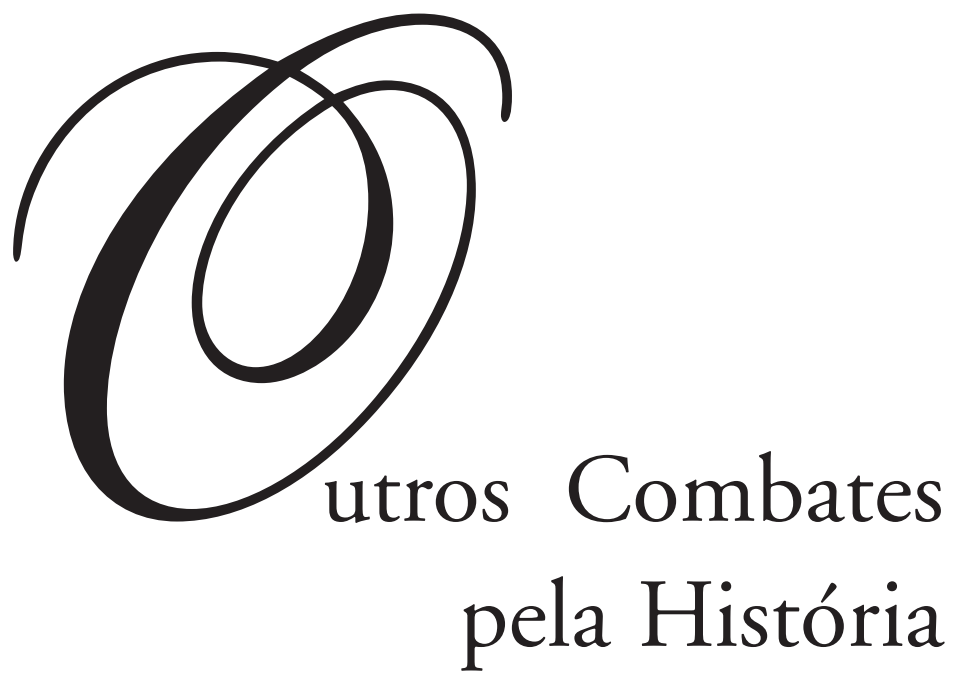

- colmbra 2010 
História, Ideias e Artes 


\section{Zília Osório de Castro}

\section{A NOSTALgia DA ETERNIDADE E O IDEÁRIO CONTRA-REVOLUCIONÁRIO}

Depois do conhecido texto de François Furet, publicado nos anos oitenta (1985) e intitulado Burke ou la fin d'une seule histoire de Europe, não mais foi possível desconhecer o antagonismo que a obra do parlamentar inglês mostrou existir entre as concepções políticas e filosóficas francesas e inglesas enunciadas e divulgadas relativamente à Revolução de 1789 . Os primeiros viam-na como uma manifestação da razão, traduzida em ideias e opiniōes consequentes. Os segundos, nomeadamente na peugada de Burke, consideravam-na como o acontecimento mais pasmoso de todos os tempos ao consubstanciar a ruptura da civilização europeia. A identidade que politicamente unira os dois países fora destruída para dar lugar à sobrevalorização do que a evolução dos tempos viera distinguir: o racionalismo empírico e histórico inglês e o racionalismo abstracto e ahistórico francês. Daqui que a legitimidade da revolução dependesse, para uns, da reconquista de uma herança e, para outros, da conquista de um tesouro. Ou seja, para aqueles ela daria continuidade ao que fora conquistado no tempo, para outros daria origem a uma nova era. Daqui que a Declaração dos Direitos do Homem e do Cidadão se tornasse em França o elemento fulcral fracturante e ao mesmo tempo estruturante da Revolução devido à sua raiz jusnaturalista, e carecesse de sentido para Burke, para quem os direitos individuais se definiam e concretizavam no interno real do todo social e expressavam simultaneamente a utilidade recíproca do ser individual e do todo colectivo.

O contributo de Burke no quadro do pensamento pós-revolucionário teria sido de contrapor dois ideários: um marcado pela continuidade e o outro pela ruptura, um pela tradição, o outro pela sua recusa. E, quanto à sua formulação partir daqui, trouxe duas concepções de tempo para o âmbito da reflexão e conceptualização política. Não havendo dúvida de que a adopção do racionalismo jusnaturalista representa o culminar do valor do temporal no ideário revolucionário, não deixa também de ser certo que trouxe uma imagem parada de tempo. A Revolução trouxe a noção de um tempo novo. Colocava os cidadãos e as instituiçôes no temporal, mas paradoxalmente situava-se a si mesma fora do tempo. Rejeitava o passado e imobilizava o presente e o futuro no quadro rígido dos conceitos. Defender que a Revolução nascera do nada e se mantinha parada no tempo era para Burke o maior dos absurdos. 
Para ele não havia presente nem futuro sem passado. Entendia a vida dos seres humanos, assim como a vida das sociedades, como um longo processo aquisitivo e ao mesmo tempo acumulativo de coisas novas. Deste modo existia uma perene interacção entre todas as geraçôes. Cada uma era subsidiária da anterior e conjugava-se com a seguinte. Isto significava que a tradição, enquanto devir no tempo, se tornava essencial à política que ele entendia como sendo um ajustamento do poder à sociedade real, e esta inseria-se na tradição como contínua adaptação às circunstâncias. Assim, o pensamento e a prática políticos não prescindiam da continuidade e esta trazia consigo a imagem fluida de tempo. O tempo histórico ganhava deste modo foros de cidadania no quadro da reflexão política como um dos elementos indispensáveis tanto à sua formulação enquanto tal, como quanto à sua compreensão e interpretação.

A crítica à Revolução francesa a partir destes enunciados e das suas consequências estão na génese do pensamento político burkeano presente nas Reflexões sobre a Revolução francesa. Confundindo tradição e tradicionalismo, ignorando a concepção de tempo que subjaz aos fundamentos teológicos da contra-revolução teocrática, os seus teóricos não só recorreram aos seus enunciados contra a revolução, como na prática o alinharam entre os seus defensores. «Pourtant — dirá François Furet - il n’y a pas grand chose en commun entre le tradicionalisme libéral du parlamentaire whig et le providentialisme de Maistre, ou la monarchie organicista de Bonald. La Contre-Révolution française ne partage avec Burke ni son sens des libertés, ni son attachement aux institutions représentatives, ni sa conception jurisprudentielle de temps, et moins que tout, bien sur, la valeuer exemplaire qu'il donne a l'histoire anglaise» ${ }^{1}$. Se bem que o pensamento de Burke estivesse longe dos princípios da Revolução francesa e também dos contra-revolucionários teocráticos, ele não deixou de ser considerado igualmente como um contra-revolucionário. A Revolução destruía a continuidade histórica que, segundo ele, naturalmente tornava perenes as instituições políticas, apesar das alterações circunstanciais que o devir histórico implicava. Como tal, a revolução em si mesma, e qualquer que ela fosse, era contrária à estabilidade política. Sendo nefasta, importava combatê-la.

Idêntico sentimento, embora ditado por princípios diferentes ressalta do pensamento de Bonald e do de Maistre. Para estes a Revolução era um mal tanto na sua doutrina, como na prática. Sem negar que fora um «événement unique dans l'histoire», Maistre não deixava de precisar "qu' elle est mauvaise, radicalement; aucun élément de bien n'y soulage l'oeil de l'observateur; c'est le plus haut degré de corruption connu;

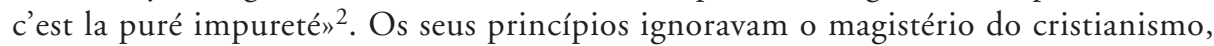
a sua prática afastava-se dos preceitos divinos. Deus enquanto origem e garante de toda a ordem política fora substituído pelo império da razão, e a vocação escatológica do ser humano viu-se reduzida ao carácter temporal da sua existência. A Revolução viera destruir a estrutura política e social que importava repor. Seria este o papel da contra-revolução.

\footnotetext{
${ }^{1}$ FrAnÇOIS FURET, «Burke, ou la fin d'une seule histoire de l'Europe», FrANÇOIS LEBRUN et RogER DepuY, org., Les résistences à la Révolution, Paris, Imago, 1987, p. 360.

${ }^{2}$ BERNARD VALADE, «Les théocrates», JEAN TULARD, dir., La contre-révbolutio, origines, histoire, postérité, Paris, Perrin, 1990, p. 301.
} 
Deus que se servira dos homens para os castigar, servir-se-ia agora deles para os colocar de novo na condição de criaturas, já que, como afirmava Maistre, a divindade "punit pour régénérer» ${ }^{3}$. Mas também com eles pretendia restabelecer a sociedade com as características que lhe atribuíra. Os seres humanos eram seres sociais e a existência da sociedade se bem que os precedesse sob o ponto de vista ontológico, congregava-os sobre o ponto de vista social. "J'ai vu dans ma vie - escrevia Maistre - des Français, des Italiens, dês Russes (...) mais quant a l'homme, je déclare ne l'avoir rencontré de ma vie» ${ }^{4}$. Por seu lado o ideal de Bonald era uma sociedade orgânica, integrada, "grupement de familles et de métiers, société agricole conçue comme ensemble de communes rurales au sein desquelles, de temps immémorial, les paysans attendent de Dieu leur subsistence et leur salut» ${ }^{5}$. Embora nem sempre concordes na doutrina enunciada, estes dois expoentes máximos do pensamento teocrático contra-revolucionário tinham em comum as suas bases fundamentais. Em primeiro lugar o providencialismo. Só este conferia sentido à vida dos homens, das sociedades e da política. Depois a crítica que daí advinha às inovações trazidas pela Revolução e ao corte com a tradição. Ao recorrerem a Deus para explicar a realidade, colocavam-na fora do tempo, ou seja, sem passado e sem futuro. Os seres humanos, o mundo e a vida referidos à acção criadora da divindade traziam indelével na sua essência o sinal da eternidade e uma perspectiva escatológica da sua razão de ser.

Por seu lado, a tradição seria a revelação no tempo dessa mesma eternidade que continuamente se realizava sem o contributo que se pudesse dar à sua formação e à sua transformação. A tradição era entendida como a vontade de Deus revelada no tempo, sendo a vontade dos homens a sua expressão. Ou seja, ela era a realização da eternidade no tempo, do dever ser que sucessivamente se revelava. Neste sentido, afirmou Bonald: «bien loin de pouvoir constituer la société, l'homme par son intervention, ne peut qu'empêncher que la société ne se constitue, ou pour parler plus exactement, ne peut que retarder le succès des efforts qu'elle fait pour parvenir a sa constitution naturelle» ${ }^{6}$.

A tradição poder-se-ia definir, portanto, como o caminhar no sentido do dever ser ao longo dos tempos, caminho que só por si se situava no plano da eternidade, já que acompanhava a acção providencial da divindade que tudo havia disposto: ao criar o homem como ser social, ditou a emergência da sociedade e do poder. Ao homem restava encontrar os meios para efectivar uma sociabilidade de origem divina, como tal, em si mesma imutável, embora na sua concretização resultasse de uma busca constante de perfectibilidade. Era este o ponto de convergência entre a providência divina e a acção humana. Dentro do imutável, o homem construía o mutável. Dentro da eternidade divina colocava-se o tempo humano. Nesta perspectiva, a tradição, no sentido acima referido, tornava-se incontornável. Fazia parte do ser humano enquanto

${ }^{3}$ Idem, ibidem, p. 301.

${ }^{4}$ Idem, ibidem, p. 306.

${ }^{5}$ Idem, ibidem, p. 296.

${ }^{6}$ Louis De Bonald, Théotie du pouvoir, Préface, p. 121, cit. por Alain PeTIT, «Burke et Bonald: les equivoques du tradicionalisme», Un lieu de memoire remantique. La Revolution de 1789, Nápoles, Vivarium, 1993, p. 54. 
ser social. O mesmo não acontecia com o tradicionalismo ao defender uma idade de ouro no passado e ao procurar fazê-lo renascer. Para os teocratas esta não existia porque contrariava as premissas escatológicas do seu modo de pensar. Seria adoptar a imagem do não tempo no plano do tempo.

O pensamento teocrático afastava-se de forma abissal do pensamento revolucionário, não só no plano político, mas também nas concepções bem mais globalizantes de cariz cultural. Ao racionalismo contrapunha-se o providencialismo, à tradição sobrepunha-se a ruptura revolucionária, à eternidade contrapunha-se o temporal, à omnipresença da religião substituía-se a sobrevalorização da metafísica laica. Sob o ponto de vista cultural estavam face a face duas concepções divergentes do ser humano, do mundo e da vida. Sob o ponto de vista político era igualmente divergente o modo de pensar os seus respectivos três suportes, ou seja, as noções de cidadão ou membro da sociedade, da própria sociedade e do poder que a regia. Sob o ponto de vista das características humanas, opunha-se a razão, "deusa da ruptura», aos sentimentos que eram inseparáveis da tradição.

Consequentemente, os seguidores dos princípios teocráticos rejeitavam a Declaração dos Direitos do Homem e do Cidadão, pedra angular da Revolução, pelo seu carácter laico e pelo seu individualismo. Rejeitavam a ideia de constituição escrita a datada, porque entendiam que a sociedade estava naturalmente constituída pela intervenção criadora de Deus. Rejeitavam a soberania popular e as formas do seu exercício, ou seja, in limine, a monarquia constitucional representativa. Numa palavra rejeitavam a Revolução nos seus princípios e nas suas consequências. Contudo, imbuídos de providencialismo e do sentido de eternidade que o acompanhava, consideravam-na, em última análise, como estando nos planos de Deus e, portanto, com um significado que ultrapassava as contingências dos tempos. Numa palavra, o tempo divino legitimava o tempo histórico ${ }^{7}$ com os seus contratempos. Perante o pessimismo radical de uns, desenhava-se o optimismo ilimitado de outros. Se a fé e a providência faziam cerrar as fileiras de uns a aposta na razão apresentava-se como a bandeira dos militantes revolucionários. Mundos completamente estanques? Talvez não. As festas revolucionárias estudadas por Mona Ozouf mostram que se os revolucionários transferiram a sacralidade com o recurso à religião, os contra-revolucionários teocráticos, nomeadamente Bonald, advogaram o regresso ao sagrado a partir da Revolução ${ }^{8}$.

Segundo se julga, todo o ideário contra revolucionário filiava-se numa destas correntes de pensamento: a "historicista» (para alguns tradicionalista), de Edmund Burke e a teocrática de Joseph de Maistre e Luís de Bonald ${ }^{9}$. Uma e outra sofreram em França e na Europa acentuações diferentes ditadas pelo contexto e pelas circunstâncias, mas o essencial manteve-se caracterizador. Se bem que, no dizer de François Furet, a

\footnotetext{
${ }^{7}$ Cfr. GÉRARd GENGEMBre, Bonald, la doctrine pour et contre l'Histoire, FranÇOIS LEBRUN et RoGER DUPUY, Les résistences á la Révolution, cit., p. 349.

${ }^{8}$ Cfr. Mona OzOUf, «Religião revolucionária», FranÇOIS Furet e MONA OzOUF, Dicionário Crítico da Revolução Francesa, Rio de Janeiro, Nova Fronteira, 1989, pp. 596-606.

${ }^{9}$ Cfr. Massimo Boffa, «La Contre-Révolution, Joseph de Maistre», The French Revolution and the Creation of Modern Political Culture, vol. 3, The Transformation of Political Culture. 1789-1848, ed. François Furet and Mona Ozouf, Oxford..., Pergamon Press, 1989, pp. 291- 321.
} 
obra de Burke marcasse o fim de uma Europa única, como já se referiu, as de Maistre e de Bonald alargaram-lhe a complexidade. História, tradição e razão tornaram-se componentes recorrentes do pensar a política e consagraram diferenças que se iriam manter e até acentuar com o passar dos anos. Deste modo, seria redutor distinguir no pensamento contra-revolucionário apenas o cânon comum, esquecendo o naipe das diferenças também elas, ou sobretudo elas, identificadoras do contraponto que se colocava à Revolução. Seja como for, uma coisa é certa. Não há contra-revolução sem haver revolução e os termos em que esta se objectiva reflectem-se inevitavelmente naquela.

Portugal recebeu os reflexos da Revolução francesa e teve a sua própria revolução liberal. E sofreu igualmente o impacto da contra-revolução. Uma e outra, como é evidente, ficaram marcadas pelo tempo e lugar em que ocorreram, o que lhes conferiu identidade própria. Tendo agora em conta o ideário da contra-revolução em Portugal, também aqui se assinalam influências das duas referidas correntes de pensamento a "historicista» e a teocrática. No entanto, a primeira nem sempre foi considerada como contra-revolucionária. Teve expressão no contexto da Revolução de vinte e, até hoje, ainda não foi suficientemente estudada. Pode, porém, apontar-se Francisco Manuel Trigos de Aragão Morato como um dos seus expoentes. Eleito deputado às Cortes de 1821, depois da Vilafrancada integrou uma comissão nomeada por D. João VI para elaborar uma proposta de constituição adequada à índole portuguesa. Se bem que se afigure evidente a filiação burkeana do seu pensamento ${ }^{10}$, nunca foi considerado como um contra-revolucionário, mas sim como um liberal moderado. Pretendia uma monarquia liberal de tipo inglês, longe dos radicalismos franceses. Ao contrário de Burke, não se manifestou contra a Revolução e, decerto por isso, sobre ele não recaiu o anátema a que aquele ficou sujeito.

Um outro nome a reter neste contexto será o de José Acúrsio das Neves que pede um estudo mais aprofundado neste sentido. Para já, importa salientar a sua rejeição da Revolução e do espírito revolucionário. Esta encerrava uma crítica à mudança e, com ela, a defesa do status quo. Neste sentido escreveu em 1823: „Para que serviria agora mudar a nossa forma de governo e dar uma constituição? Para melhorar a sorte da nação? Não é preciso. Estamos muito bem com a constituição que temos e todas as mudanças de governo são perigosas» ${ }^{11}$. Neste mesmo sentido censurou os direitos individuais, sobretudo a liberdade e o carácter de valor absoluto que lhe era atribuído pela Revolução. A liberdade teria de ser controlada pelo poder estabelecido sob pena de se tornar libertária e introduzir na sociedade o caos e a desordem. Só o seu constrangimento se adequava à vida humana e ao seu aperfeiçoamento ${ }^{12}$. As revoluções

${ }^{10}$ Cfr. Pedro PÁscon Martins, Ideologia e temporalidade. As ideias politicas de Francisco Manuel Trigoso (1777-1838), Lisboa, FCSH/UNL, 1995. Dissertação de Mestrado em História Cultural e Política.

${ }^{11}$ José ACÚRSIO DAS NEves, «Continuação das Cartas aos Portugueses. Seguem-se as que foram escritas depois da restauração do governo legítimo de sua Magestade», Obras completas de José Acúrsio das Neves, t. IV, Porto, Afrontamento, s. d., p. 105.

${ }^{12}$ Cfr. António Pedro Mesquita, O Pensamento Político Português no século XIX, Lisboa, Imprensa Nacional-Casa da Moeda, 2006, pp. 312, 314. 
eram um mal pela ruptura que provocavam ao contrário das reformas que, não só eram naturais, como desejáveis. Obviavam que se caminhasse para "a velhice» das instituiçōes. Estas podiam manter-se vivas se se actualizassem sob o signo da ordem e de acordo com os costumes e a história. Ou seja, entendia a política como contextualizada no tempo e no lugar, sofrendo positivamente a evolução ditada pela experiência concreta da vivência humana. Contrapunha, assim, a imagem do tempo que fluía sem cessar à ruptura revolucionária assente na abstracção das ideias que, neste modo de pensar, nada tinham a ver com a realidade histórica dos povos. E afastava, igualmente como politicamente improcedente, a ideia de não tempo, de eternidade, por não se coadunar com o sentido que atribuía à política.

Embora no âmbito de um ideário diverso poderá juntar-se a estes dois a presença de Faustino José da Madre de Deus Pereira Coutinho, autor de vários textos, entre os quais se salienta um que intitulou Os povos e os reis e publicou em 1825. Esta obra representa a permanência do «historicismo» de cariz burkeano, com recorrência à tradição nos termos em que aquele o fazia com nítida recusa da Revolução e de todas as revoluções. "As revoluções subversivas são (...) abomináveis e calamitosas", sublinhava, e eram-no porque alteravam a ordem existente ${ }^{13}$. Mas as reformas eram possíveis e até desejáveis desde que realizadas por quem tivesse autoridade para as fazer. Dizia: «Eu não insto para que os povos sejam escravos da monarquia absoluta; não me oponho a que esta adquira qualquer grau de perfeição de que seja susceptível, pugno unicamente para que ela não seja reformada por quem não tem autoridade de a reformar» ${ }^{14}$. Não se afigura que houvesse aqui laivos do liberalismo conservador de Burke ${ }^{15}$ porque a tradição histórica que utilizou no contexto da recusa da Revolução corria no sentido da defesa da legitimidade da monarquia absoluta, embora não a defendesse como o única forma de governo ${ }^{16}$.

Saliente-se, todavia, que não recorreu ao discurso providencialista, facto que o afasta da família dos teocratas. Pelo teor das suas palavras, poderá sim ser considerado como expoente particularizado da corrente do "historicismo» contra-revolucionário. Este particularismo reside no facto de Faustino da Madre de Deus integrar o tempo no seu pensamento, embora esquecendo ou minimizando as circunstâncias que lhe trariam o sentido da mudança. É certo que admitia as revoluçôes, mas também é certo que acima de tudo colocava a ordem e a conservação, ideias que apontam no sentido da permanência, se não da perenidade. Teria sido no quadro deste eventual duplo sentido que invocou as Cortes de Lamego e as Leis Fundamentais ali instituídas como ponto de partida e fundamento da situação política então criada e que os povos legitimamente não poderiam alterar em virtude do contrato então realizado, se bem que a pudessem aperfeiçoar.

\footnotetext{
${ }^{13}$ Faustino José da Madre de Deus Pereira Coutinho, Os povos e os reis: opuscuplo offerecido aos portuguezes, Lisboa, Impresa Régia, 1825, p. 96.

${ }^{14}$ Idem, ibidem, p. 99.

15 Cfr. António Pedro Mesquita, ob. cit., p. 385.

${ }^{16}$ São estas as suas palavras: "pugno pela conservação de todas as formas de governo; e logo não sou parcial de governo algum, sou unicamente amigo da ordem» (Idem, ibidem, 97).
} 
Paralelamente a esta corrente do ideário contra revolucionário houve também quem seguisse a peugada de Maistre e de Bonald, adoptando o seu modo de pensar igualmente com particularismos próprios. Nomeia-se como um destes autores Filipe Neri Sousa Avelar. Geralmente identificado como legitimista, empenhado na defesa de D. Miguel como rei de Portugal, o seu ideário serviria para fundamentar os seus régios direitos. Usou para isso uma tríplice argumentação — histórica e jusnaturalista, coroada com a invocação da providência de Deus como ponto culminante do seu modo de pensar. Pelo lugar que esta ali ocupava mais que pela economia do discurso que, como o autor referiu, se centrava nos princípios do Direito natural, pareceria ser adequado colocá-lo entre o número dos teocratas, embora se tenha consciência de ser uma opção discutível.

$\mathrm{Na}$ apresentação do seu pensamento em defesa dos direitos de D. Miguel recorreu, tal como Faustino da Madre de Deus, às Leis Fundamentais e às Cortes de Lamego onde foram promulgadas. Ora, invocar estes factos do passado para reforçar a defesa de uma situação do presente não deixa de ter um duplo sentido. Por um lado indicia que a legitimidade política tinha, segundo ele, raízes históricas. Por outro que essa mesma legitimidade resultava da permanência dessas mesmas raízes. Ou seja, o discurso histórico tomava o sentido do discurso da tradição que, sem pretender um retorno ao passado, tornava presente esse mesmo passado. Assim o entendeu, em parte, Filipe Neri Soares de Avelar ao publicar o seu opúsculo de apoio a D. Miguel como rei de Portugal. Segundo o autor, "os portugueses deram o trono em 1139 ao seu primeiro e ínclito monarca e fizeram nas Cortes de Lamego as primeiras Leis Fundamentais da monarquia» e deram-no sucessivamente a D. João I e D. João $\mathrm{IV}^{17}$. Por fim, continuava o Autor, usaram desse mesmo direito, reconhecendo D. Miguel como seu legítimo rei e senhor chamado ao trono por essas mesmas Leis no preciso momento em que seu pai faleceu, 10 de Março de 1826.

Contrariamente ao que se poderia pensar, estes casos concretos da História de Portugal, no entender de Filipe Avelar, embricavam teoricamente numa doutrina universal que, também ela tivera expressão durante o consulado pombalino. Referimo-nos ao direito natural moderno longamente invocado na sua filiação pufendorfio-wolfiana. Para defender os direitos de D. Miguel este autor citou Grocio, Pufendorf, Wolff e Vattel juntamente com De Real e Montesquieu para fundamentar a legitimidade do seu direito à sucessão. Entendia ele, apoiado no magistério destes autores, que a nação podia conceder ao seu chefe a autoridade e os direitos que lhe aprouvesse sem quaisquer restriçôes. Daqui que estes fossem idênticos aos da sociedade política que lhos atribuíra e que quando esta os depositasse nas mãos de uma só pessoa esta adquiria o título de Rei. Nas suas palavras: «Podendo a Nação conceder ao seu Chefe o grau de autoridade e os direitos que lhe parecer, ela não é menos livre a respeito do nome, dos títulos e das honras com que o quiser condecorar. Se o Chefe do estado é Soberano, ele tem na sua mão os direitos e a autoridade da Sociedade Política e, por consequência; ele mesmo pode prescrever o seu título e as honras que se lhe devem render $(\ldots){ }^{18}$.

${ }^{17}$ Filippe Neri SOARes De AVElar, A legitimidade da exaltação do muito alto, e muito poderoso rei, O senhor D. Miguel Primeiro, ao Throno de Portugal, demonstrada por princípios de direito natural e das gentes, Lisboa, Na Impressão Regia, 1828, pp. 37-38.

${ }^{18}$ Idem, ibidem, p. 18. 
Soares Avelar não ficou por aqui na defesa dos direitos que pretendia defender. Invocou ainda o direito divino, lembrando que «a Coroa de Portugal não dependia senão de Deus», se bem que "só o povo tivesse o direito de eleger o rei»" ${ }^{19}$ (35). Isto significa que apesar da influência do jusnaturalismo moderno, o Autor professava a doutrina da origem divina do poder. Este seria transmitido mediatamente ao rei por intermédio do povo. Além disso, sendo Deus "o Supremo árbitro dos impérios» ${ }^{20}$ e o homem "árbitro do mundo" prescrevia a todos os seres regras universais que a todos obrigavam. Daqui que, em última análise; o Autor sem descurar a História, nem a modernidade jusnaturalista, mantivesse a tradicional fé na acção providencialista da divindade. Sendo assim, a ideia de não-tempo, de eternidade, sobrepunha-se à perenidade da evocação da história e do direito natural, a qual transmitia uma imagem parada de tempo. Sendo assim, colocava a política no plano abstracto e a-temporal dos princípios, fora do concreto da sua prática.

António Joaquim de Gouvea Pinto trouxe uma outra amplitude ao providencialismo político, apenas esboçado pelos autores anteriores. Salientou que Deus ao criar o primeiro homem criara igualmente o primeiro rei e confiara-lhe a autoridade, a eleição e o domínio que lhe eram adequados. A partir daqui concluía que «reinam os reis não por eleição humana, não por capricho nem por pacto livre dos homens, não por necessidade nem por acaso, mas pelo mesmo Deus que os elege com eleição eterna ${ }^{21}$. Deu-lhes um poder absoluto e instituiu a sucessão como meio quase exclusivo de garantir a continuidade do seu poder e de consagrar a hereditariedade do trono como a forma mais perfeita do cumprimento dos seus desígnios. Os legisladores portugueses acataram restes princípios e deram-lhes forma de lei. Assim se decretou a legitimidade e legalidade da doutrina segundo a qual «o príncipe soberano recebendo de Deus imediatamente o supremo poder e autoridade, não reconhece na terra superior algum temporal (...) que está livre da força coactiva da lei, porque a lei tem toda a sua força do poder do príncipe (...) que é sobre a lei e que nenhuma por ele feita o pode obrigar» ${ }^{22}$.

Estavam assim enunciados os princípios fundamentais da monarquia pura de origem divina que poderia ser eterna. Não porque não admitisse reformas. Mas porque estas não podiam contrariar as «leis fundamentais da monarquia» que garantiam a forma de governo «estabelecida por Deus em Portugal» ${ }^{23}$. Gouvea Pinto plasmava deste modo a ideia de eternidade na doutrina enunciada. Esta recebia de Deus a sua imutabilidade e tal como ele, estava fora do tempo. Isto não significava que a partir daqui não enunciasse a possibilidade de um contínuo aperfeiçoamento das instituições políticas e que, por isso mesmo, não demonstrasse sensibilidade ao devir histórico e, daí, à prática política que fora seguida ao longo do tempo, tanto em Portugal como

${ }^{19}$ Idem, ibidem, p. 35

${ }^{20}$ Idem, ibidem, p. 41

${ }^{21}$ ANTONIO JOAQUim DE GOUVEA PINTO, Os caracteres da monarquia, Expostos em resumo, para o fim de mostrar ao mesmo tempo a preferência, que ela merece entre as mais formas de Governo. Offerecidos a Sua Magestade Elrei D. João VI, N. Senhor. Lisboa, Na Impressão Regia, 1824, pp. 6-7.

${ }^{22}$ Idem, ibidem, p. 27.

${ }^{23}$ Idem, ibidem, p. 29. 
em diversos países. Criticava-a ou defendia-a, tendo como referência os princípios acabados de expor. E mais. Apontava os efeitos calamitosos que haviam decorrido da sua não observância. O sentido da temporalidade que acompanha a imagem fluida de tempo atravessava todo o seu discurso, tendo como pano de fundo nunca esquecido a ideia de eternidade. Seria esta, aliás, a dar sentido à vida que se vivia.

Torna-se interessante salientar que no quadro da monarquia pura de direito divino, característico de uma certa modernidade, desponta a contemporaneidade representada pelo devir no tempo e que alguém que defendia estas ideias se tornasse num acérrimo defensor da legitimidade de D. Miguel. È verdade que para o fazer invocou as Leis de Lamego e os princípios do direito público português, além da providência e do direito natural e das gentes, socorrendo-se ainda do discurso histórico para tornar claro que D. Miguel tinha o poder ipso jure, sem necessitar nem de aclamação nem de coroação e que a convocação de Cortes nem era de Direito fundamental nem elas teriam voto deliberativo para defender a sua legitimidade como rei de Portugal, aliando neste caso concreto, o temporal e o eterno para atingir o seu objectivo $^{24}$.

Idêntica aliança entre a eternidade da lei e da providência divinas e a perenidade da Leis Fundamentais da monarquia encontra-se, se bem que em termos diferentes, em José Agostinho de Macedo e em Frei Fortunato de São Boaventura. Para o primeiro, religião e política eram faces de uma mesma moeda, o que significava que encarava a política como uma das facetas da perspectiva de todo o real. Daqui resultava uma interpretação providencialista da política e dos acontecimentos políticos. Neste último sentido escreveu: "A Divina Providência que tão visivelmente vigia sobre os destinos de Portugal, guardava a vida do seu legítimo soberano no coração, como guardou no templo de Jerusalém o Menino Jesus (...). Por um fio de milagres nunca interrompido, contra a esperança, contra as manobras péssimas dos seus gorados inimigos, conduziu D. Miguel ao Reino (...) para o assentar no trono dos seus maiores» ${ }^{25}$. Os factos políticos, nomeadamente o regresso do legítimo rei a Portugal resultavam, pois, da aliança simultânea do providencialismo divino e do "voto e proclamação unânimes do povo» ${ }^{26}$.

Sendo assim, defendeu a legitimidade de D. Miguel contra as expectativas dos defensores da soberania de D. Pedro. De forma positiva, apoiou-se, para isso, nas Leis Fundamentais aprovadas em Lamego e nas decisōes dos Três Estados do Reino quanto à ordem da sucessão. Recorrendo a argumentação de cariz negativo, criticou os revolucionários vintistas e cartistas, acusando-os de terem ultrapassado decisões seculares referentes à monarquia portuguesa. Acusou-os de rebelião e de terem levado a cabo um movimento "democrático e republicano» contrário à tradição e à legalidade ${ }^{27}$.

${ }^{24}$ Veja-se Idem, Demonstração dos direitos, que competem ao Senhor D. Miguel I. sobre a successão da Coroa de Portugal, legitimidade da sua acclamação feita pelas Câmaras do Reino com o Clero, Nobreza e Povo: autoridades destas Câmaras, e das Côrtes de Portugal, a este respeito, Lisboa, Na Impressão Regia, 1828.

${ }^{25}$ JosÉ AgOSTINHO DE MACEDO, Refutação do monstruoso, e revolucionário escripto impresso em Londres intitulado Quem he o Legitimo Rei de Portugal? Questão portugueza submetida ao juizo dos homens imparciais, Londres impresso na officina portugueza 1828, Lisboa, Na Impressão Regia, 1828, p. 63.

${ }^{26}$ Idem, ibidem, p. 63.

27 Cfr. Idem, ibidem. 
No caso em apreço, mostrou-se adepto da perenidade dos textos fundadores e da possibilidade da sua perene utilização. Parece evidente, portanto, que lhe faltava sensibilidade para integrar no seu discurso a imagem fluida de tempo própria da dinâmica histórica e permanecia adepto do valor abstracto do temporal. Era neste que enquadrava o relato dos acontecimentos como singular expressão de determinações aprovadas de uma vez para sempre. Fundamentava a legitimidade de D. Miguel em resoluçôes tomadas no passado que se acreditava pertencerem ao presente. Caracterizava-as a perenidade e não a historicidade. José Agostinho de Macedo transmitia esta forma de pensar quando se referiu ao paralelismo entre as declaraçôes das Cortes de Lamego e a sua própria actualidade: «Não queremos outro rei senão D. Afonso Henriques disseram aqueles primeiros portugueses; não queremos, dizem os portugueses existentes, senão o mui alto e muito poderoso rei e soberano, o senhor D. Miguel I, que Deus visivelmente prospera e que Deus por sua paternal providência nos conservará» 28 .

Esta dupla legitimidade resultava da acção criadora de Deus ao criar o homem como um ser social. Por isso, ele era essencialmente um ser «nascido para a sociedade dos seus semelhantes» ${ }^{29}$ pelo que todos os aspectos da sua sociabilidade, inclusive a política, estavam marcados indelevelmente na própria natureza. Por sua vez, cada associação tinha em si regras próprias que faziam parte da sua essência enquanto tal. Sob o ponto de vista político, por exemplo, não tinha sentido falar de uma constituição nova, já que a constituição era em si mesma perene, como perenes era cada um dos seus membros ${ }^{30}$. Consequentemente, Deus não era apenas o criador da sociedade mas também o seu legislador. Sem as suas leis ela caminharia para a dissolução. A partir daqui, Agostinho de Macedo concluía que a realidade temporal das nações era o reflexo da sua essência perene: «Há quase sete séculos que a nação não reconhece, nem tem, nem quer ter outra Lei Fundamental mais que o Pacto primordial de Lamego, conservado intacto» 31 .

Frei Fortunato de São Boaventura não se afastou significativamente desta forma de pensar quer em geral quanto à aliança da política e da religião, quer em particular em relação às Leis Fundamentais e às Cortes de Lamego, apesar de não estarem na origem da realeza de $\mathrm{D}$. Afonso Henriques, pois que «muito antes que o saudassem e aclamassem rei no Campo de Ourique» 32 já era reconhecido como tal. As Cortes apenas haviam confirmado pelo direito, o que já existia de facto. $\mathrm{O}$ poder régio tinha origem divina: "o rei dos reis comunica o seu poder e autoridade aos reis da terra» ${ }^{33}$, afirmava, apontando para o enunciado da origem divina directa e imediata da soberania.

${ }^{28}$ Idem, ibidem, p. 79.

${ }^{29}$ Idem, Bazes eternas da Constituição Politica achadas na cartilha de Mestre Ignacio, Lisboa, Impressão Rua Formosa, 1824, p. 38.

30 «Não pode fazer-se uma constituição nova porque ela está feita e depositada eternamente na mesma essência e natureza do homem", dizia (Idem, ibidem, p. 40).

${ }^{31}$ Idem, Refutação..., cit., p. 13.

32 Frei Fortunato de SĀo Boaventura, Lisboa, Tip. Maygrense, 1829, n. o 6, p. 24.

${ }^{33}$ Idem, Instrução Pastoral do Arcebispo de Évora aos seus diocesanos sobre a obediência que devem ao mui Alto e Poderoso Senhor D. Miguel I, Lisboa, 10 de Junho de 1632, p. 6. 
Pelo mesmo princípio - a vontade de Deus - a monarquia hereditária era a mais conforme com a sua natureza. E também ela fora criada por Deus. Por seu lado, a "reunião indissolúvel do rei com o povo português» ${ }^{34}$ prescrita pelas Leis Fundamentais era expressão da unidade política hierarquizada com raízes na teoria da origem divina directa e imediata da soberania régia e nos atributos dos reis. Enfim, a aliança da religião e da política até aqui enunciada sob o ponto de vista teórico, tinha incidências práticas, caracterizadas pela excelência da sua caracterização. Atente-se no sentido destas palavras: «Felizes, dourados tempos e eternamente saudosos foram por certo esses dias em que os portugueses foram unânimes em dar a César o que é de César, sem faltarem nunca á outra dívida mais forte e mais sagrada qual é pagar a Deus o que é de Deus» ${ }^{35}$.

$\mathrm{Na}$ continuidade da sua reflexão, Frei Fortunato lembrava que Portugal havia vivido "seiscentos anos de monarquia" que haviam sido seiscentos anos de "glória», por ter mantido a fé na prudência e misericórdia divinas ${ }^{36}$. Haviam sido "as doutrinas subversivas e destruidoras da ordem social» que haviam aberto o caminho às heresias religiosas ${ }^{37}$ ou porque punham em causa as verdades imutáveis da religião ou porque não respeitavam os justos limites da jurisdição de cada uma delas. Nestes termos, criticava a "abusiva» intervenção dos poderes políticos na vida da Igreja, de clara influência regalista, assim como identificava os liberais pela sua impiedade pois "desertando da bandeira da lealdade, desertavam igualmente da bandeira da fé» 38 . Só D. Miguel e o que ele representava em termos políticos, seriam abençoados por Deus, por estarem de acordo com a sua doutrina. À Igreja e a si próprio como um dos seus membros pertencia defendê-los para que renascessem os dias gloriosos em que Portugal tornasse de novo a ser a "nação mais católica do universo" ${ }^{39}$.

Não restam dúvidas, se dúvidas pudesse haver, que a imagem última de tempo perfilhada por Frei Fortunato de São Boaventura era a da eternidade. Imbuído da ideia de que Deus estava presente e explicava a existência e a vida dos seres humanos só ela lhes dava sentido e sem ela tudo seria nulo. Ao mesmo tempo, parece intuir que o não-tempo, a eternidade, que afinal se identificava com a divindade, não excluía a vida no tempo se vivida de acordo com os princípios da religião cristã, em todas as actividades humanas, nomeadamente na política. De igual modo, parece igualmente poder intuir-se dos seus escritos que à Igreja pertencia uma função social, se não política, que desempenharia mediante uma aliança com o estado, dentro dos parâmetros da jurisdição de cada um.

${ }^{34}$ Idem, Gazeta de Lisboa, 8 de Julho de 1828.

35 Idem, Instrução pastoral...cit., p. 1.

${ }^{36}$ Idem, «Protestação do Arcebispo de Évora, Fr. Fortunato de S. Boaventura contra o scisma declarado em a cidade do Porto», VisConde de SANTARÉm, Correspondência Política e Diplomática, p. 517.

37 Oração Gratulatória que na solemne acção dos habitantes da Cidade de Coimbra endereçaram ao todo poderoso, por verem restituido a Portugal o Senhor D. MIGUEL I. O Desejado recitada em a Igreja Parochial de S. João de Almedina a 11 de Maio do presente anno por Frei Fortunato de S. Boaventura, Monge de Alcobaça, Coimbra, Real Imp. da Universidade, 1828, p. 3.

${ }^{38}$ Idem, Protestação...cit., p. 519.

${ }^{39}$ Idem, ibidem, p. 518. 
A estes nomes outros se poderiam juntar alargando o campo da reflexão. Lembremos os de António Ribeiro Saraiva e de José da Gama e Castro, assim como o do próprio D. Miguel, se bem que não raras vezes entre eles o discurso da perenidade sobreleve o da eternidade. Embora os seus particularismos, sem dúvida por isso mesmo, enriquecessem esta abordagem, o essencial da problemática terá ficado suficientemente delineado para poder ser aprofundado na temática que se pretendeu focar. Isto é, a ideia de eternidade como um dos aspectos a salientar no pensamento contra-revolucionário nos seus atributos compreensivos-interpretativos, assim como na comparação que é possível estabelecer com as ideias de perenidade, de temporalidade e, enfim, no confronto com a emergência do temporal. 

Série

Documentos

Imprensa da Universidade de Coimbra

Coimbra University Press

2010

- U

C • 